\title{
グアニジノ化合物の経時的変動よりみた短時間透析の検討
}

\author{
藤 城 敏高長谷川 寛 柳井利之島邦義水野雅夫 \\ 小川 正川島司郎三浦信彦*1 三戸部京子*1 池亀守*1 \\ 藤田学園保健衛生大学内科 同腎センター*1
}

(昭和 61 年 11 月 17 日受付)

key words：グアニジノ化合物, 短時間透析, メチルグアニジン

〈要旨〉

血液透析患者 21 名を対象に, 一般血清生化学検查に加え, グアニジノ化合物濃度を測定し, 透析時間による臨床的 影響の判断におけるパラメーターとなり得るかどうかを検討した。

その結果，1）一般血清生化学検査値の中では, BUN, creatinine およびUA の透析 4 時間值と 5 時間值の間に有 意差があったが $(p<0.05), 4.5$ 時間值と 5 時間值の間に有意差はなかった。 2 ) 週 30 分間透析時間を短縮したが, その前後 3 カ月間のデータ集計では, 透析前の血清 creatinine 值は 6 例中 5 例で有意に増加し $(p<0.005)$, BUN も 2 例で有意に増加した。3）血清および全血中のグアニジノコハク酸, メチルグアニジンは, 4 時間值に比べ 5 時間 值では，低下傾向はあったが有意差はなかった４４）Creatinine の経口負荷によりメチルグアニジンは約 2 倍に増加 した。 その後の透析においても 4 時間値と 5 時間值の間に有意差はなかったが, 5 時間值でも非負荷時の約 2 倍の值 を示し, 透析効率はクレアチニンよりも低かった.

以上の事より, 通常の血液透析法による短時間透析では, メチルグアニジンの蓄積が生ずる可能性が示され, 長期 間の観察が必要と思われる.またメチルグアニジンの毒性を重要視するならば, protein permeable HDF のような血 液浄化法で透析時間の短縮を図った方が良いと思われた。

\section{Study of short-term dialysis via guanidino complex variations with time}

Toshitaka Fujishiro, M. D., Hiroshi Hasegawa, M. D., Toshiyuki Yanai, M. D., Kuniyoshi Kojima, M. D., Masao Mizuno, M. D., Tadashi Ogawa, M. D., Shiro Kawashima, M. D., Nobuhiko Miura*1, Kyoko Mitobe*1 and Mamoru Ikegame*1

Department of Internal Medicine and Kidney Unit*1, Fujita Gakuen Health University

Twenty-one dialysis patients were subjected to serum biochemical studies in which guanidino complex variations were observed in order to determine whether or not they would be helpful in determining the advisability of short -term dialysis. The results of these investigations were as follows 1) In serum biochemical studies, significant differences were observed between the four-hour and five-hour dialysis values for BUN, creatinine and UA $(p<$ 0.05 ), but no significant differences were noted between the 4.5 - and five-hour values ; 2) dialysis time was reduced by $30 \mathrm{~min}$ per week and the categorized data totals for an approximate three-month period indicated a significant increase in predialysis serum creatinine values in five of six patients $(p<0.005)$ and also a significant increase in BUN in two patients ; 3) guanidino succinic acid and methylguanidine values in both serum and whole blood showed a tendency to be lower in the five-hour period in comparison with values for the four-hour period, but the differences were not significant ; 4) methylguanidine was approximately doubled by a creatinine peroral load. Thereafter, there were no significant differences between the values obtained in the four-hour and five hour dialysis procedures, although even the values for the five-hour period were approximately double those for non -loading. Dialytic efficiency was lowered to a greater extent than creatinine levels.

藤城 敏高 藤田学園保健衛生大学内科

干 470-11 豊明市沓掛町田楽ヶ窪 1-98（0562-93-2239） 
According to the possibility observed that methyl-guanidine accumulasion occurs in short-term dialysis performed by conventional dialysis methods, the above data indicate that long-term observation is necessary. If methylguanidine toxicity is regarded to be important, then shortening of the dialysis process by blood purification methods such as protein-permeable HDF in advisable.

\section{緒言}

透析方法の改良や, 高性能膜の開発とともに, 透析時 間を短縮する目的で様々な試みがなされている，時間短 縮による患者への影響を評価するために種々のパラメー ターが用いられているが，何をもって適切な透析の指標 とし, 時間短縮の可否を判定するかとなると, 現在のと ころ確立されたものはない。

本研究では従来の一般血清生化学検査に加え, いわゆ る “uremic toxin”の代表とみなされてきたグアニジノ 化合物が, 血液透析においてどのような経時的変動を示 すかを観察し，透析時間短縮の可否の判断に対し一助と なり得るかどうかを検討したので報告する.

対象・方法

本院の慢性血液透析患者 21 名（男 12 名, 女 9 名, 年 齢 22〜75 歳, 透析歴 2 力月～9 年)を対象に，次の上う な臨床研究を行った。

1. 血清生化学検査值と血中グアニジノ化合物濃度の 経時的変動

5 時間透析の開始前と, $3,4,4.5$ お よび 5 時間経過 時に, 動脈側血液回路より採血し, 血清生化学検査とグ アニジノ化合物分析を施行した。

2.クレアチニン負荷後の血液透析におけるグアニジ ノ化合物の経時的変動

40 60 歳の男性 3 名, 女性 3 名において, 血液透析の 開始 20 時間前にクレアチニン $30 \mathrm{mg} / \mathrm{kg}$ を経口投与し
た上で， 5 時間透析におけるグアニジノ化合物の経時的 変動を観察した。

3 . 透析時間の短縮による一般血清生化学検查值への 短期的影響

1 回 5 時間, 週 3 回の血液透析を, 週末の 1 回のみ 4.5 時間に短縮し，短縮前後の各 3 力月間の生化学検査值を 集計し，時間短縮の影響を検討した。この場合，時間以 外の透析条件は変更していない.

\section{測定法}

グアニジノ化合物の分離には，島津社製，陽イオン交 換樹脂カラム（ISC-05/SO504）を用いた高速液体クロ マトグラフィーを使用した。

移動相に pH 3.5 11.8 の 4 種の液を用いたグラジエ ント溶離法にて試料を分離し，ニンヒドリンによる螢光 法で検出した（励起波長 $500 \mathrm{~nm}$, けい光波長 $395 \mathrm{~nm}$ ). 全血㧍よび血清は，30\%トリクロール酢酸にて除蛋白後 (終濃度 10\%)，ミリポア社 milex GV フィルターにて 濾過し, その濾液を試料とした。標準液には, 和光純薬 製, グアニジノ化合物混合標準液に, $0.5 \mathrm{mg} / \mathrm{d} l$ のクレア チンを付加した物を使用した。

\section{結果}

1. 表 1 は 5 時間透析に抢ける血清生化学検査值の経 時的変動である. 表に示した諸検査值の 4 時間值と 5 時 間值とを比較すると, BUN, UA, creatinine の 5 時間值 は 4 時間值よりも有意に低下していた $(\mathrm{p}<0.05) .4 .5$

表 1 透析による諸物質濃度の経時的変動 対象（男 3 例，女 4 例） $\mathrm{n}=21$

\begin{tabular}{|c|c|c|c|c|c|c|}
\hline & & 前 & 3 & 4 & 4.5 & 5 時間 \\
\hline BUN & $\mathrm{mg} / \mathrm{d} l$ & $68.5 \pm 11.5$ & $32.3 \pm 5.3$ & $26.1 \pm 4.6$ & $23.5 \pm 4.9$ & $20.1 \pm 5.0$ \\
\hline Creatinine & $\mathrm{mg} / \mathrm{d} l$ & $9.3 \pm 1.1$ & $4.7 \pm 0.6$ & $4.1 \pm 0.5$ & $3.8 \pm 0.5$ & $3.4 \pm 0.4$ \\
\hline UA & $\mathrm{mg} / \mathrm{d} l$ & $7.6 \pm 0.7$ & $3.1 \pm 0.6$ & $2.4 \pm 0.5$ & $2.1 \pm 0.4$ & $1.9 \pm 0.3$ \\
\hline $\mathrm{Na}$ & $\mathrm{mEq} / \mathrm{l}$ & $138.0 \pm 3.1$ & $138.0 \pm 1.4$ & $137.4 \pm 1.0$ & $137.7 \pm 1.5$ & $137.7 \pm 2.1$ \\
\hline K & $\mathrm{mEq} / l$ & $4.7 \pm 0.6$ & $3.4 \pm 0.4$ & $3.1 \pm 0.3$ & $3.1 \pm 0.4$ & $3.1 \pm 0.3$ \\
\hline $\mathrm{Cl}$ & $\mathrm{mEq} / l$ & $107.0 \pm 3.0$ & $101.1 \pm 2.6$ & $100.5 \pm 2.3$ & $101.3 \pm 3.1$ & $102.9 \pm 2.7$ \\
\hline $\mathrm{Ca}$ & $\mathrm{mg} / \mathrm{d} l$ & $8.9 \pm 0.5$ & $9.3 \pm 0.5$ & $9.3 \pm 0.8$ & $9.7 \pm 0.7$ & $9.8 \pm 0.9$ \\
\hline $\mathrm{P}$ & $\mathrm{mg} / \mathrm{d} l$ & $4.9 \pm 0.8$ & $2.6 \pm 0.3$ & $2.4 \pm 0.3$ & $2.4 \pm 0.3$ & $2.2 \pm 0.3$ \\
\hline $\mathrm{HCO}_{3}^{-}$ & $\mathrm{mmol} / l$ & $20.9 \pm 3.0$ & $26.1 \pm 3.8$ & $27.2 \pm 3.9$ & $28.3 \pm 4.4$ & $27.7 \pm 3.6$ \\
\hline
\end{tabular}


表 2 透析時間短縮による諸検査值への影響（週 3 回 5 時間透析の 1 回のみ 30 分間短縮,

短縮前後の各 3 力月間の検查值を比較 $)$

\begin{tabular}{|c|c|c|c|c|c|c|c|c|c|c|c|c|c|c|}
\hline & \multicolumn{2}{|c|}{$\mathrm{BUN}(\mathrm{mg} / \mathrm{d} l)$} & \multicolumn{2}{|c|}{ Crea $(\mathrm{mg} / \mathrm{d} l)$} & \multicolumn{2}{|c|}{$\mathrm{TP}(\mathrm{g} / \mathrm{d} l)$} & \multicolumn{2}{|c|}{$\mathrm{Ht}(\%)$} & \multicolumn{2}{|c|}{$\mathrm{K}(\mathrm{mEq} / l)$} & \multicolumn{2}{|c|}{$\mathrm{Ca}(\mathrm{mg} / \mathrm{d} l)$} & \multicolumn{2}{|c|}{$\mathrm{P}(\mathrm{mg} / \mathrm{d} l)$} \\
\hline & Pre & Post & Pre & Post & Pre & Post & Pre & Post & Pre & Post & Pre & Post & Pre & Post \\
\hline (35 歳, $\hat{\jmath})$ & $93.9 \pm 9.2$ & $94.4 \pm 5.5$ & $14.7 \pm 0.6$ & $\begin{array}{c}15.5 \pm 0.5 \\
* *\end{array}$ & $6.3 \pm 0.3$ & $\stackrel{6.6 \pm 0.3}{\sim_{*}}$ & $21.0 \pm 0.6$ & $21.0 \pm 1.0$ & $4.3 \pm 0.3$ & $4.3 \pm 0.3$ & $9.0 \pm 0.5$ & $9.0 \pm 0.5$ & $3.0 \pm 0.7$ & $2.6 \pm 0.6$ \\
\hline (78歳, 令) & $89.4 \pm 11.1$ & $90.3 \pm 8.5$ & $11.9 \pm 0.6$ & $\begin{array}{c}12.8 \pm 0.4 \\
* *\end{array}$ & $6.8 \pm 0.3$ & $6.9 \pm 0.2$ & $21.8 \pm 1.0$ & $21.6 \pm 1.4$ & $4.8 \pm 0.3$ & $\stackrel{5.1 \pm 0.4}{\underbrace{}_{*}}$ & $9.1 \pm 0.7$ & $9.2 \pm 0.8$ & $4.3 \pm 0.4$ & $4.2 \pm 0.5$ \\
\hline$(60$ 歳, $\hat{\delta})$ & $70.1 \pm 8.6$ & $70.1 \pm 8.9$ & $15.2 \pm 0.5$ & $\begin{array}{c}15.9 \pm 0.3 \\
* *\end{array}$ & $6.8 \pm 0.3$ & $6.9 \pm 0.2$ & $29.0 \pm 1.5$ & $30.0 \pm 1.4$ & $4.4 \pm 0.3$ & $\stackrel{5.1 \pm 0}{* *}_{* * 6}$ & $9.0 \pm 0.3$ & $9.3 \pm 0.4$ & $4.2 \pm 0.5$ & $4.1 \pm 0.6$ \\
\hline (83 歳, $\hat{\delta})$ & $82.4 \pm 29.5$ & $89.2 \pm 9.7$ & $10.1 \pm 1.2$ & $\begin{array}{r}13.1 \pm 0.7 \\
J_{* *}\end{array}$ & $5.9 \pm 1.9$ & $6.6 \pm 0.2$ & $23.7 \pm 1.7$ & $\underset{* *}{28.7 \pm 1.8}$ & $4.6 \pm 0.5$ & $4.5 \pm 0.2$ & $8.8 \pm 0.6$ & $9.3 \pm 0.8$ & $4.3 \pm 0.9$ & $4.3 \pm 0.7$ \\
\hline (48歳, 守) & $113 \pm 0.4$ & \begin{tabular}{|c|}
$126 \pm 13.6$ \\
${ }_{*}$
\end{tabular} & $11.8 \pm 0.4$ & $\begin{array}{c}12.5 \pm 0.4 \\
* *\end{array}$ & $7.1 \pm 0.3$ & $7.2 \pm 0.2$ & $17.2 \pm 1.3$ & $17.9 \pm 1.9$ & $4.1 \pm 0.2$ & $4.2 \pm 0.4$ & $10.8 \pm 1.3$ & $9.9 \pm 0.5$ & $5.7 \pm 0.6$ & $5.9 \pm 0.9$ \\
\hline (51歳, q) & $90.3 \pm 9.8$ & $\frac{102 \pm 14.1}{*}$ & $11.1 \pm 0.4$ & $\begin{array}{c}11.4 \pm 0.5 \\
{ }_{* *}\end{array}$ & $6.4 \pm 0.2$ & $6.6 \pm 0.3$ & $21.6 \pm 0.9$ & $22.1 \pm 0.9$ & $5.4 \pm 0.5$ & $4.9 \pm 1.7$ & $9.1 \pm 0.4$ & $9.1 \pm 0.5$ & $5.1 \pm 0.8$ & $5.2 \pm 0.6$ \\
\hline
\end{tabular}

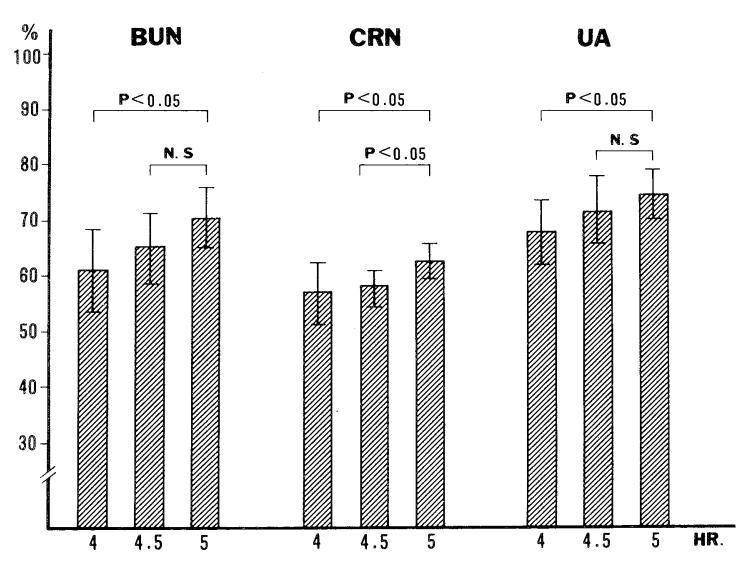

図 1 透析効率の経時的変動（症例数 7 例, $\mathrm{N}=$ 21)

時間値と 5 時間値の間には有意差はなかった。 BUN, UA, クレアチニンの透析効率を経時的にみると, 図 1 の ように 3 者とも 4 時間值と 5 時間值の間では有意差があ り $(\mathrm{p}<0.05)$ ，クレアチニンは 4.5 時間值と 5 時間値の 間でも有意差があった。

5 時間透析中に血清グアニジノ化合物の濃度を経時的 に測定したが，その中でも代表的なクレアチン，クレア チニン, guanidinosuccinic acid (以下 GSA と略す) および Methylguanidine (以下 MG) の成績を図 2 に示 した. GSA, MG は経時的に減少するが，4 時間值と 5 時間值の間に有意差はなかった. Creatine は, 2 時間目 以降はほぼプラトーとなっている。

図 3 は同様に, 全血でのグアニジノ化合物の経時的変
動である。変動の様子は血清の場合とほぼ同様であった が，透析前の全血 MG は血清の場合と比べると約 1.7 倍， 5 時間值でも約 1.7 倍の高值を示した。

2.困 4 にはクレアチニン $30 \mathrm{mg} / \mathrm{kg}$ を経口投与し, その 20 時間後に開始した透析中の血清グアニジノ化合 物の変動を示した。図 5 は同じく全血での変動である.

クレアチニンの経口負荷により, 血清 GSA 值は負荷 前の平均 $293.1 \mu \mathrm{g} / \mathrm{d} l$ から平均 $118.7 \mu \mathrm{g} / \mathrm{d} l$ に減少. 全 血でも平均 $257.9 \mu \mathrm{g} / \mathrm{d} l$ から平均 $160.1 \mu \mathrm{g} / \mathrm{d} l$ に減少し た（透析前值での比較）。

逆に血清 $\mathrm{MG}$ は平均 $20.9 \mu \mathrm{g} / \mathrm{d} l$ から平均 $45.2 \mu \mathrm{g} / \mathrm{d} l$ に増加. 全血でも平均 $35.1 \mu \mathrm{g} / \mathrm{d} l$ から平均 $56.1 \mu \mathrm{g} / \mathrm{d} l$ に 増加した(同じく透析前值での比較)。この増加した $\mathrm{MG}$ は血清，全血とも透析により次第に低下するが，4 時間 值と 5 時間值の間に有意差はなかった。しかし,血清 $\mathrm{MG}$ の 5 時間值は平均 $26.4 \mu \mathrm{g} / \mathrm{d} l$ と非負荷時の平均 $9.2 \mu \mathrm{g} /$ $\mathrm{d} l$ に比べ， 3 倍近い高濃度を示している。これは非負荷 時の透析前值よりも高い值である.

3.以上の成績にもとづいて，時間以外の透析条件を 変更することなく，比較的状態の安定した患者 6 例（男 4 名，女 2 名）を選び，1回 5 時間，週 3 回の透析を， 週末の 1 回のみ 4.5 時間に短縮することにした。その時 間短縮実施前後 3 力月間のデータを集計したものを表 2 に示す。

短縮後, BUN は 4 例で上昇傾向を示し, 2 例の女性で は有意に上昇した $(\mathrm{p}<0.05)$.

クレアチニンは 6 例中 5 例で有意に上昇 $(\mathrm{p}<0.05)$. Ht. は 3 例がわずかに上昇傾向を示し，1例の男性で有 


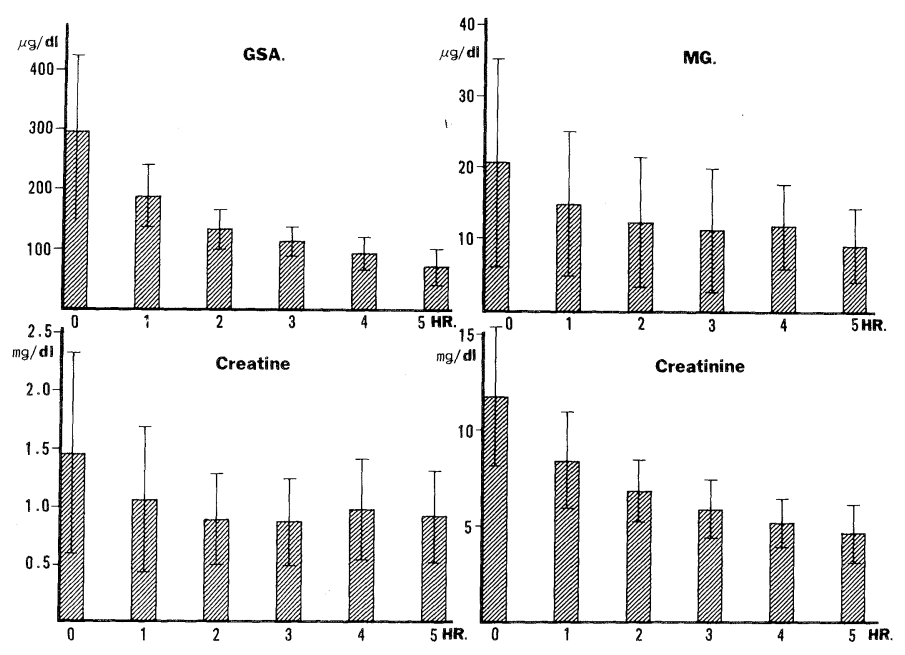

図2透析時の血清グアニジノ化合物の変動 $(n=6)$

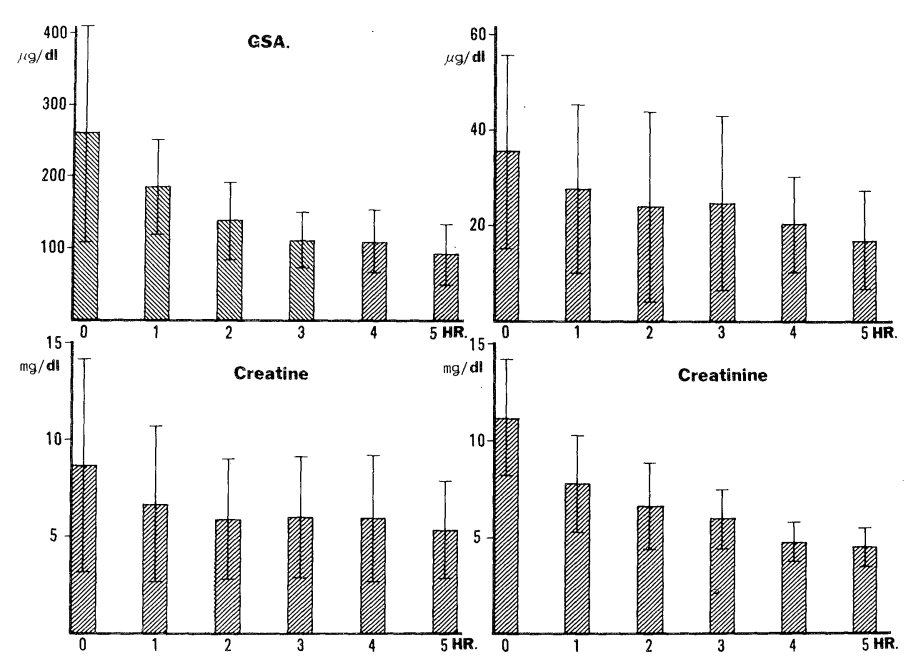

図 3 透析時の全血グアニジノ化合物の変動 $(\mathrm{n}=6)$

意 $(\mathrm{p}<0.005), \mathrm{K}^{+}$は 3 例で不変, 1 例で低下傾向があ り，2 例の男性で有意に上昇した。Caは 1 例が低下傾向 を示したが, 有意差はなく, $\mathrm{p}$ はとんど不変であった。

\section{考案}

5 時間透析における，4.5 時間と 5 時間での血清生化 学検查値には有意差が認められず, グアニジノ化合物の 測定值でも, 4 時間と 5 時間では有意差がなかったので, 1 週間あたり 30 分間の透析時間短縮を行った。

その影響を，短縮前後 3 力月間のデー夕を集計して比 較したが, BUN とクレアチニンが上昇した例が多く, 特 にクレアチニンは 6 例中 5 例と高率に上昇し, 僅か 30 分 間の短縮でも，窒素代謝産物の除去の上に明らかな影響
がみられた。

一方, 血清蛋白と $\mathrm{Ht}$ が有意に上昇した例が各 1 例み られ, 時間短縮による血中アミノ酸損失の減少, 透析後 の不均衡症候群の軽減による食欲の増進等により, この ような例が生じたのかもしれないが, 西堀らの, 週 9 時 間透析まで短縮した 2 症例は, 約 1 年の経過中に有意差 はないものの, Ht は低下傾向を示しており ${ }^{1)}$,これらに ついてはさらに長期間の観察を要すると思われる。

グアニジノ化合物，その中でも MG は，腎不全患者の 体内で異常増加するが，これは排泄低下によるのではな く, 産生増加によるものとされており, この産生経路は 種々想定されているが，現在のところクレアチン 

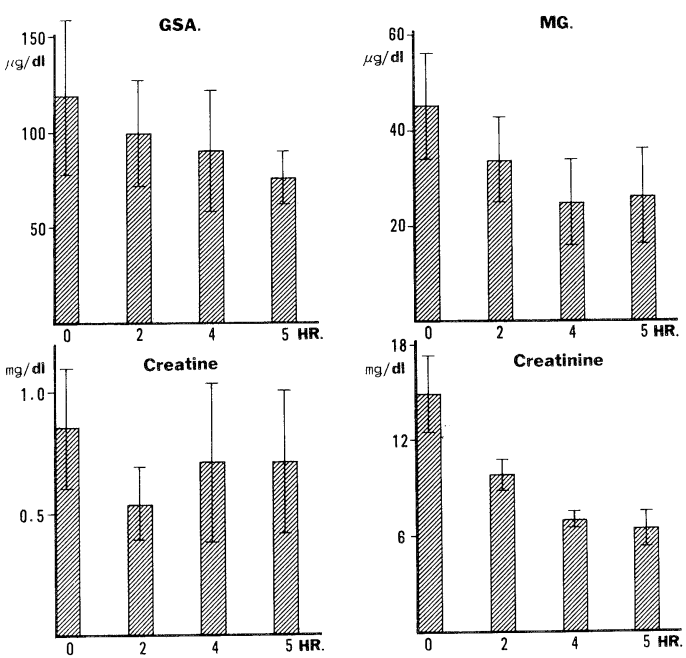

図4 クレアチニン負荷後透析時の血清グアニジ ノ化合物の変動 $(\mathrm{n}=6)$
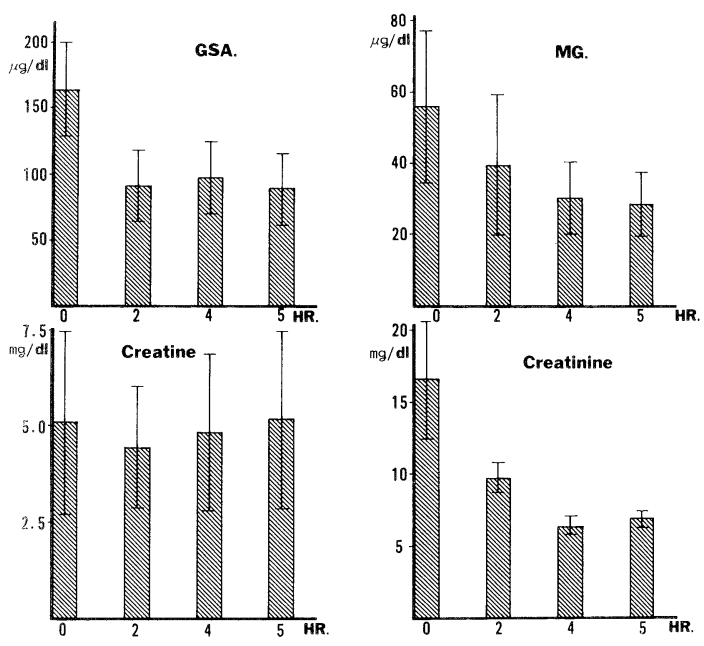

図 5 クレアチニン負荷後透析時の全血グアニジ ノ化合物の変動 $(\mathrm{n}=6)$

アチニン $\rightarrow \mathrm{MG}$ が主経路とされており, 今回我々がクレ アチニンを経口投与した結果でも, MG は約 2 倍に増加 した。

この MGの透析による経時的変動をみると,クレアチ ニン負荷時, 非負荷時とも, 透析 4 時間値と 5 時間値の 間に澺差はなかった。これは，通常の透析方法では $\mathrm{MG}$ の透析効率が悪いため差が出にくかったと考えられ る.

19 ?3 年の Giovannetti らの報告によると, MG は 73 という分子量にもかかわらず,蛋白結合性を有するため,
透析されにくいとされており，今回の我々の研究におい て，5時間透析における血清 $\mathrm{MG}$ の除去効率は平均 $48.8 \%$ で，クレアチニンの $61.0 \%$ に対し，10\%以上低い 結果であった。また，クレアチニン負荷後に約 2 倍に増 加した MG は, 透析 5 時間值でも非負荷時の 5 時間值の 約 2 倍の值であり, これは非負荷時の透析前値よりも高 值であったが，これも MGの低透析性の結果と考えられ る。

山本らの報告では，5時間透析における $\mathrm{MG}$ の除去効 率は $55 \%$ ，クレアチニンは $62 \%$ とれており，彼らは MG の透析性は良いとしている゙仿，クレアチニンより は悪い結果がでている。しかし最近の磯田らのように， MG の除去効率は BUN と同一とみなし得だ备という報 告もあり, 今後さらに検討が必要と思われる。

これまで MG には種々の毒性が報告されてきており， uremic toxin と目されるものの中でも重要物の 1 つと 思われてきたが，測定法が改良されるにつれ，過去の毒 性実験での血清 $\mathrm{MG}$ 濃度は, 現在の測定值よりもはるか に高濃度であるとする報告が多くなった ${ }^{6 \sim 8)}$. しかし, 椿 原, 安東らは, 慢性腎不全患者の血球内と, 慢性腎不全 rat の各藏器内 $M G$ 濃度を測定し, これらは in vitroで の毒性発現濃度に匹敵するとしている ${ }^{7,8)}$. 今回の我々の 成績でも, 血清濃度と全血濃度から血球内 $M G$ 濃度を推 定すると, 平均 $140 \mu \mathrm{g} / \mathrm{d} l$ と, 血清濃度の約 4 倍に及ぶ と考えられる。

これらの事を総合して考えると, 現時点では, MGは 可能な限り除去した方が良いと考えるのが妥当と思われ るが，通常の血液透析法では不十分のようである.

短時間透析を実施した報告では, 西堀ら ${ }^{1)}$, Chapman

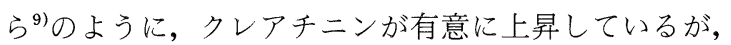
我々も今回の研究で, わずか週 30 分間の短縮で, 高率に クレアチニンの有意な上昇を観察している.このことか らは, 安易に時間短縮を行うと, クレアチニンより透析 による除去効率の劣る $\mathrm{MG}$ の蓄積が生ずる可能性が示 唆される。

短時間透析の方法について，太田らは HDF の有用性 をのべており ${ }^{10)}$, 後藤らのように短時間透析の手段は, 1 回あたり $10 l$ 以上の置換液量を用いる hard HDF，ある いは置換液の組成を変えることにより少量の置換液量に て効率良くHDF を行うという soft HDF の 2 方法に限 られると述べる者もいる。

$\mathrm{HDF}$ は, HD 単独に比べ，小分子物質，中分子物質の 除去能にすぐれているわけであるが，さらに protein perneable HDF としたならば，MG のような低分子だ が蛋白結合性物質の除去という点については非常に有用 と思われる。 


\section{まとめ}

今回，グアニジノ化合物，中でも代表的な $\mathrm{MG}$ の経時 的変動を観察し, 透析時間短縮の可否の判断の一助とな り得るかどうか検討したが，通常の透析での 4 時間値と 5 時間值の間に有意差はなく, 透析による除去率はクレ アチニンよりも悪く, 通常の透析方法での時間短縮は $\mathrm{MG}$ の蓄積を生ずる可能性が示唆された。

MG を uremic toxinの 1 つとみなし, その除去を計 るならば, protein permeable HDF のような方法にて透 析時間短縮を計った方が良いと思われ, 今後, 各種血液 浄化法によるグアニジノ化合物の除去につき検討してみ たいと思う。

\section{文献}

1）西堀文男, 荒 隆一: 短時間透析. 臨床透析, 1 : 81-87, 1985.

2) Mikami, H., Orita, Y., Ando, A., Fujii, M., Kiuchi, T., Yoshihara, K., Okada, A. and Abe, H. : Metabolic pathway of guanidio compounds in chronic renal failure. Adv. Exp. Med. and Biol., 153 : 449 $-458,1982$.

3) Giovannetti, S. and Barsotti, G.: Dialysis of methylguanidine. Kidney Intern, 6 : 177-183, 1974.

4) 山本征夫, 万治忠福, 斎藤 明, 前田憲志, 太田和
宏，小林快三：メチルグアニジンと適性透析.人工 臟器 $7: 30-33,1978$.

5）磯田和雄, 御手洗哲也, 今村典嗣, 長沢龍司, 広瀬 悟, 杉本健一：透析療法に㧍けるメチルグアニジン の除去効率と血中濃度に関する臨床的研究 : 第 9 回 グアニジノ化合物研究会, 講演要旨集, p 56-57, 1986.

6）下条文武：腎不全に抢ける Guanidine 誘導体の研 究. 日腎誌, XVI : 53-62, 1974.

7）安東明夫, 中田一洋, 椿原美治, 田中敏博, 阿部 裕： 尿毒症の病態とUremic Toxin-Guanidine 誘導体. 最近医学, 31:1695-1706, 1976.

8）椿原美治：慢性腎不全時に打ける methyl -guanidine の研究〈特に methylguanidine の測定 法と, その藏器内濃度の検討〉。日腎誌 XX : 371-380, 1978.

9) Chapman, G. V., Mahony, J.F., Farrell, P.C. : linical Nephrology, $13: 78-84,1980$.

10）鈴木利昭，西堀文男，太田和夫，酒井良忠，鬼沢美 知子, 国友哲之輔, 菊地哲也: 無症状短時間透析の 検討. 人工藏器, $11: 182-185,1982$.

11）後藤 健, 中川成之輔：短時間透析. 腎と透析, 21 : 71-77, 1986. 